\title{
Fishing as Therapy: Impacts on Job Satisfaction and Implications for Fishery Management
}

\section{Introduction}

Consideration for the well-being of natural resource users is one regarded as an integral part of ecosystem-based policy strategies to conserve natural resources and maintain essential ecosystem services (Bowen and Riley 2003; UNEP 2006; Abunge et al. 2013; Daw et al. 2016). In the United States, National Standard 8 of the Sustainable Fisheries Act of 1996 requires that potential adverse socio-economic impacts to communities resulting from the implementation of management strategies be explicitly considered and minimized (MSFCMA 2007). The past decade has seen increased effort by fishery social scientists to understand and operationalize human dimension factors influencing fishery policy and management, including individual and community well-being (Smith and Clay 2010, Coulthard et al. 2011, Weeratunge et al. 2012, Daw et al. 2011, Armitage et al. 2012, Pollnac and Poggie 2008). The concept of well-being has often been associated with financial status and measured objectively using variables such as income per capita and education level, however there is an emerging consensus that such objective measures alone are poor indicators or predictors of well-being. Here we adopt a broader definition of well-being; one that includes individual perceptions of happiness and satisfaction with their lives.

Job satisfaction is a significant aspect of individual and community well-being in general (Pollnac et al. 2008, 2011) and especially among fishers. Aspects of the occupation of fishing such as "adventure," "freedom," and "being outdoors" have been linked to high levels of job satisfaction among fishers worldwide (Apostle et al. 1985; Binkley 1995; Pollnac and Poggie 1988, 2008; Pollnac et al. 2008). High levels of job satisfaction are, in turn, associated with strong attachment to and reluctance to leave the occupation of fishing even in the face of economic hardship, a finding supported by several recent studies (e.g., Crosson 2014; Pascoe et al. 2015; Sweke et al. 2016; Trimble and Johnson 2013). This reluctance coupled with other important social attributes (e.g. age and education) make it more difficult for fishers to seek and obtain alternative employment outside the fishing industry. As Sweke et al. (2016) note, this in combination with environmental transformations associated with human impacts such as stock depletion and climate change pose important and increasing challenges for fishers and policymakers alike in many parts of the world.

Collaborative approaches that take into account stakeholders' well-being and basic needs are associated with more effective natural resource management strategies as these are perceived to be fairer, resulting in higher levels of acceptance and compliance (Kildow et al. 2014). Thus, increasing our understanding of aspects of well-being among fishers and their attitudes toward their occupation in different geographic areas, allowing for an investigation of the commonalities 
that unify fishing peoples as well as their differences, will contribute to the development of more appropriate, case-specific, and robust strategies for the conservation and management of marine resources in the future. This study presents unique comparisons, across space and time, regarding aspects of fishers' perception of their job satisfaction and well-being between two geographic areas where fishing constitutes integral part of the local economy and culture: the Northeast Region US and the Caribbean.

Examining differences in aspects of job satisfaction and well-being in such highly different environments (both human and natural) will provide information for developing models to understand how different stressors (e.g. changes in the natural, socio-cultural, economic and managerial environments) affect those whose livelihoods depend directly on fishery resources. Models elucidating relationships between environmental and anthropogenic changes and the well-being of resource dependent populations will provide indispensable input for the development of strategies that incorporate both natural and human objectives in preserving and maintaining essential ecosystem services.

\section{Aspects affecting job satisfaction and well-being: Caribbean vs New England fishers}

As part of a paper exploring stresses involved in the occupation of fishing, Pollnac et al. (2011) found that with regard to satisfactions in connection with their occupation, fishers in the Caribbean, except for Jamaica, were more satisfied with aspects reflecting social and psychological attributes such as social relationships and relaxed mental states than fishers from New England, United States. They interpret this as reflecting the Caribbean fishers' relatively short fishing trips in peaceful waters in contrast to the longer trips and more turbulent waters fished by the US fishers. They further suggest that their findings may be related to Griffith and Valdes-Pizzini's (2002) description of Puerto Rican fishers who consider their work as 'therapy', as healthy or a sport, in comparison with other occupations they had pursued. They write that fishers returning from other land-based work "return to the sea, to fishing, to work in a job that offers therapy for their disability or for the alienation accumulated during so many years of mindless, repetitive labor" (Griffith and Valdes-Pizzini 2002: 32). Similarly, Glazier (2007) indicates that Hawaiian fishers employed in typical, land-based jobs commonly cite fishing as a primary means of escaping from the pressures and stresses of other types of work. Many years ago, Pollnac and Poggie (1980) and Pollnac and Ruiz- Stout (1977) also found that fishers from Costa Rica and Panama state that fishing is like a sport and that it is suave (smooth, soft).

In addition to the factors mentioned above, other aspects are believed to have contributed to the differences found in Pollnac et al. (2011) between Caribbean and New England fishers. In the past couple of decades, the Northeast Region of the US (Maine south through North Carolina) has been continuously affected by major changes in fishery management to address dwindling fish stocks, which has been shown to result in additional stresses among fishers in the region (Pollnac et al. 2015). These types of stresses, induced by coping with a restrictive management 
regime, are not present in the non-US Caribbean and are much less present in Puerto Rico, where management has been less restrictive and less coercive and where fishers have historically engaged in multi-species fisheries, have had greater latitude in adapting to restrictions, and have had coping strategies available, such as occupational multiplicity and value adding through petty commodity seafood marketing (Griffith and Valdes-Pizzini 2002; Pérez 2005). This fishing regulatory environment was much like New England fishers' experience in the late 1970s when the Fishery Conservation and Management Act (FCMA) was first passed. However, since the passage of the act in 1976, regulations governing New England fishers evolved to the rapidly changing, extremely complex and increasingly restrictive system of single stock management, which exists today in the region. Such differences in managerial environments are likely to influence fishers' attitudes towards the activity, which are expected to result in differences regarding levels of job satisfaction and well-being.

In this paper, relationships using subjective job satisfaction and well-being variables were tested with new data from the Northeast (NE) Region US ${ }^{1}$ and Southeast (SE) Puerto Rico. Though the main focus of the study was on comparisons of the SE Puerto Rican and NE Region US fishers, data from the late 1970s for one important New England port, Point Judith, Rhode Island, was used to provide a comparable historic context for the NE Region, and data from other Caribbean fisheries (Belize, Nicaragua, Dominican Republic, and Jamaica) were used to provide a comparable context for the SE Puerto Rican fishery. Fishers in all areas studied were compared with regard to their levels of perceived job satisfaction and, in the foci areas, subjective overall well-being was analyzed in relationship to job satisfaction and important demographic variables. The primary objective of this study is to further investigate aspects affecting well-being of fishery resource users to inform the decision-making process of factors that may affect or contribute to the success of management strategies to conserve fish stocks worldwide.

\section{Methods}

\subsection{Sample}

Between 2009 and 2013 a total sample of 738 fishers was interviewed face-to-face in fishing communities in the NE Region U.S. $(\mathrm{N}=478)$, SE Puerto Rico $(\mathrm{N}=47)$, and four other nonU.S. Caribbean and Central American countries (referred to as the wider Caribbean sample) $(\mathrm{N}=$ 213). Additionally, a sample of 79 fishers interviewed face-to-face in Point Judith, RI in 1977 was used for a temporal comparison.

The surveys were conducted as part of separate data collection efforts in each area studied with the job satisfaction and well-being questions being posed consistently in all regions except when

\footnotetext{
${ }^{1}$ NOAA Fisheries defines the Northeast Region U.S. as all coastal states from Maine to North Carolina.
} 
noted otherwise. Data on age and education of fishers interviewed was also collected for the entire sample (Table 1).

Table 1.

Distribution of fisher mean age and education across studied areas

\begin{tabular}{lccc}
\hline Location & Age & Education & N \\
\hline S. New England & 44.0 & 12.5 & 236 \\
N. New England & 45.3 & 12.4 & 86 \\
Mid-Atlantic & 46.8 & 12.6 & 156 \\
Puerto Rico & 44.6 & 9.5 & 47 \\
Belize & 46.3 & 5.7 & 31 \\
Nicaragua & 39.3 & 5.8 & 26 \\
Dominican Republic & 42.5 & 5.9 & 130 \\
Jamaica & 30.7 & 10.8 & 26 \\
Point Judith 1977 & 33.9 & 11.8 & 79 \\
\hline
\end{tabular}

The NE Region US sample was obtained in various fishing ports (N 50) in the region between 2009 and 2010. The sampling technique used was an intercept approach at docks and places where fishers gathered. This sampling method was considered appropriate to obtain a representative sample of fishers in the locations studied because it maximizes response rates for hard-to-find individuals (Miller et al. 1997), such as crew, for whom no registry or comprehensive lists are available. For purposes of analysis, the NE Region US sample is divided into three sub-regions: Northern New England ( $\mathrm{N}=86$, Maine and New Hampshire), Southern New England ( $\mathrm{N}=236$, Massachusetts, Rhode Island, and Connecticut) and the Mid-Atlantic ( $\mathrm{N}$ $=156$, New York, New Jersey, Delaware, Maryland, Virginia, and North Carolina). All fishers in the sample can be categorized as commercial, i.e. characterized by the landing of fish and other seafood for sale to market. Target species differ somewhat between the three geographic areas, with lobster (Homarus americanus) being the focus of most in Northern New England; scallops (Placopecten magellanicus), groundfish ${ }^{2}$, lobster, squid ${ }^{3}$, and crabs $^{4}$ in Southern New England, and mixed other finfish, groundfish, scallops, crabs and other shellfish in the Mid-Atlantic. Fishing operations in all ports visited in the NE Region US are considered large scale with

\footnotetext{
${ }^{2}$ Includes both small mesh [Silver hake (Merluccius bilinearis), red hake (Urophycis chuss), and offshore hake (Merluccius albidus)] and large mesh [Atlantic cod (Gadus morhua), haddock (Melanogrammus aeglefinus), pollock (Pollachius virens), yellowtail flounder (Limanda ferruginea), witch flounder (Glyptocephalus cynoglossus), winter flounder (Pseudopleuronectes americanus), windowpane flounder (Scophthalmus aquosus), American plaice (Hippoglossoides platessoides), Atlantic halibut (Hippoglossus hippoglossus), redfish (Sebastes fasciatus), ocean pout (Zoarces americanus), and white hake(Urophycis tenuis)].

${ }^{3}$ Includes both longfin [Doryteuthis (Amerigo) pealeii (Loligo squid)] and shortfin [Illex illecebrosus (Illex squid)].

${ }^{4}$ Includes deep sea red crab (Chaceon quinquedens), Jonah crab (Cancer borealis), blue crab (Callinectes sapidus) and other unspecified species of crabs.
} 
vessels ranging between approximately 40 and 80 feet and trip length ranging from day trips to as long as 15 days. The most frequently used gear types are trawls, dredges (scallop and hydraulic), and lobster traps. Data collected in 1977 and used here for temporal comparative purposes were obtained in Point Judith, RI $(\mathrm{N}=79)$, a port, which at the time was composed of primarily short trip multispecies trawlers and day-trip lobster boats (trip length mean $=1.66$ days, mode $=1$ ).

The SE Puerto Rican sample $(\mathrm{N}=47)$ consists of structured interviews conducted between 2012 and 2013 in the rural and highly fishery-dependent (Griffith et al. 2007) coast of SE Puerto Rico, as part of a project investigating the relationships between the use of coastal resources and the well-being of people living along this coastline (Garcia-Quijano et al. 2013, 2015). Respondents were randomly selected and stratified by 1) community of residence, and 2) participation in marine-reef or estuarine/coastal forest fisheries, locally known as pesca de monte (GarciaQuijano et al. 2016). All respondents can be considered commercial small-scale fishers with a large part of their household income coming from local coastal resources (Garcia-Quijano et al. 2013). The fishers engage in short (1-2-day) trips in small (12-27 feet), outboard powered boats, targeting multiple finfish, more than 60 species; including mackerels (Scomberomorus regalis and S. cavalla) and a variety of snappers and groupers (E.g. Lutjanus vivanus, L. analis., L. synagris, Epinephelus guttatus, E. adsencionis) and shellfish species (e.g. Panulirus argos; Strombus gigas; Octopus vulgaris) with varied capture techniques over the continental shelf or offshore seamounts.

Data from other Caribbean fisheries were collected between 2009 and 2010 and were used here to provide context for the SE Puerto Rican data. The Dominican Republic survey was conducted using structured questionnaires in six coastal provinces, five along the north coast - a region that hosts the largest fishing population in the country - and one along the east coast. A total of 130 fishers were interviewed using intercept sampling method. The fishers are small-scale, using traps, gill nets, hand lines and diving, usually capturing queen conch (Lobatus gigas), spiny lobster (Palinuridae) and king mackerel (Scomberomorus cavalla). Fishing in the areas studied is characterized by day trips of 4 to 8 hours in duration.

The Jamaican sample $(\mathrm{N}=26)$ consists of trap fishers and divers targeting primarily spiny lobsters from six communities located in Westmoreland parish-one of four parishes with the highest production of lobster in Jamaica. In contrast to the other Caribbean fishers in the sample, who are day fishers, some of the Jamaican fishers go for 8-9 day fishing trips to Pedro Bank, located some $80 \mathrm{~km}$ away from the mainland (Monnereau and Pollnac 2012). In Belize $(\mathrm{N}=31)$, the survey was administered to a sample of trap and dive lobster day trip fishers in Caye Caulker and Belize City, respectively. In Nicaragua $(\mathrm{N}=26)$, the survey was carried out on Corn Island, which is responsible for half of the spiny lobster landings in Nicaragua. Three lobster harvesting types are practiced on the island. The sample included 18 small-scale trap fishers, 4 industrial trap fishers and 4 small-scale divers. The fishing activity in both Belize and Nicaragua is characterized by day trips. 


\subsection{Measures}

\subsubsection{Job Satisfaction}

In keeping with a long history of research on job satisfaction in the fishery (Acheson et al. 1980; Apostle et al. 1985; Pollnac and Poggie 1988; Binkley 1995; Poggie et al. 1995; Glazier 2007; Bavinck 2012; Sweke et al. 2016; Pascoe et al. 2015; Seara et al. 2016), the concept "job satisfaction" will be used in this paper to refer to satisfaction with select occupational attributes (see list in Table 2). The 9-item scale used in this study originated from a list of 22 indicators used by Poggie and Gersuny (1974: 56), which contained items adapted from Schletzer's (1965) 62-item scale designed to measure general job satisfaction in U.S. culture plus four items unique to the occupation of fishing. Most of the items used were related to high-frequency responses to open-ended interviews with 108 southern New England fishers who were requested to report what they "liked and disliked about fishing." For many decades most of the items were consistently used to measure job satisfaction among fishers (Anderson 1980; Apostle et al. 1985; Binkley 1995; Bunce et al. 2000; Gatewood and McCay 1990; McCay et al. 1993; Pollnac and Poggie 2006; Pollnac et al. 2011; Smith 1981). Principal component analysis of the job satisfaction items using data from different geographic locations and throughout time have consistently revealed three components characterized as Basic Needs, Social \& Psychological Needs, and Self-Actualization (Table 2) (see Pollnac and Poggie 1988 and Seara et al. 2016 for a thorough description). The component that has been most consistent and highly rated in terms of satisfaction across most fisheries studied using the job satisfaction variables is the SelfActualization component. This component includes aspects of the fishing occupation related to items such as adventure, independence, and the challenges of being out on the water, which are regarded as important factors affecting fishers' well-being (Pollnac and Poggie 1988, Glazier 2007, Pollnac and Poggie 2006).

Since the original list is relatively long (usually around 22 items), Pollnac et al. (2015) conducted a data reduction effort using a factor analysis of the items from a geographically diverse data set and selected items with the highest loadings on each of the three components commonly found reducing the number of indicators for each component to the three that manifested the highest loadings on each component. Multiple correlations between these top three items and the factor

scores for each component were high enough $\left(\mathrm{R}^{2}=0.79\right.$ and above $)$ to accept them as reliable representatives of each component. For each item concerning fishing occupation attributes, respondents are asked about their satisfaction level on a scale ranging from 1 to 5 with 1 representing very dissatisfied, 5 very satisfied, and 3 neutral. These values are summed for each job satisfaction component resulting in a scale that varies between 3 and 15, with a median of 9. The items are validated by a principal component analysis of the NE Region US and SE Puerto Rican data collected in this study which places them in the expected components with the three components explaining 58 percent of the variance in the data set (Table 2). 
Table 2

Rotated Component Matrix (VARIMAX) of variables of Job Satisfaction in fisheries in SE Puerto Rico \& NE Region US

\begin{tabular}{llll}
\hline Occupation Attributes & $\begin{array}{l}\text { Self- } \\
\text { Actualization }\end{array}$ & Basic Needs & $\begin{array}{l}\text { Social \& } \\
\text { Psychological }\end{array}$ \\
\hline Challenge & $\mathbf{0 . 8 2 2}$ & 0.133 & 0.056 \\
Adventure & $\mathbf{0 . 8 0 4}$ & 0.088 & 0.056 \\
Opportunity to be own boss & $\mathbf{0 . 6 4 9}$ & 0.014 & 0.255 \\
Predictability of earnings & 0.027 & $\mathbf{0 . 8 5 2}$ & 0.105 \\
Earnings & 0.148 & $\mathbf{0 . 8 3 0}$ & -0.016 \\
Safety & 0.063 & $\mathbf{0 . 4 1 3}$ & 0.312 \\
Healthfulness & 0.182 & -0.068 & $\mathbf{0 . 7 5 6}$ \\
Fatigue & 0.111 & 0.120 & $\mathbf{0 . 7 4 4}$ \\
Time away from home & 0.054 & 0.202 & $\mathbf{0 . 6 9 8}$ \\
Percent Variance Explained & 20.05 & 18.37 & 19.92 \\
\hline
\end{tabular}

Use of this well-established multivariate measure of job satisfaction answers Pascoe et al. (2015) suggestion that "[...] future work should consider identifying more specific domains of satisfaction with fishing that can support improved understanding of how management changes affect fisher satisfaction [...]." Pascoe et al. (2015) used a single measure, a 10-point Likert scale reflecting a fisher's response to a single question concerning satisfaction with the occupation of fishing. In addition to the 9-item scale, this study also analyzed two other widely-accepted measures of job satisfaction (Pollnac and Poggie 1988; Robinson et al. 1969) reflecting responses to the following questions: 1) Would you advise a young person to enter the occupation of fishing, and 2) If you had your life to live over would you still become a fisher?

\subsubsection{Well-Being}

Overall individual well-being, was measured in the two main regions studied, NE Region US and SE Puerto Rico, using a single indicator, response to the question: "In general, how satisfied are you with your life?" Answers to the question were recorded on a 5-point Likert scale ranging from very dissatisfied to very satisfied. Oswald and $\mathrm{Wu}$ (2010) have presented objective confirmation of the validity of this measure indicating that among a random sample of 1.3 million US citizens there was a significant, strong correlation between subjective well-being and objective estimates of quality of life that have been widely employed by economists (2010: 579).

\section{Analysis}

The first step in the analysis was a comparison of mean scores on all three job satisfaction components between SE Puerto Rico and the three NE Region US sub-regions using non- 
parametric analysis of variance (Kruskal-Wallis $\mathrm{H}$ ) (Table 3 and Figure 1). Differences on all three components are statistically significant $(\mathrm{p}<0.001)$, and the plot in Figure 1 as well as values in the table clearly indicate the degree to which SE Puerto Rico differs from the three subregions of the NE Region US. Additionally, all mean scores are above the mid-point (9) indicating that fishers are, overall, generally satisfied with their occupation. It is the differences between the samples that bear examination.

To help understand differences between the NE Region US and SE Puerto Rico, data from Point Judith, RI obtained in 1977, as well as data from the four countries in the wider Caribbean sample, are entered into the analysis. Table 3 compares means across all samples and these values are also plotted in Figure 1. Differences are statistically significant (Kruskal-Wallis analysis of variance all $\mathrm{p}<0.001$, Table 3), once again distancing SE Puerto Rico from the contemporary NE Region US, but this time also indicating that the SE Puerto Rican fishers differ significantly from the countries included in the wider Caribbean context. While quite different than contemporary NE Region US, SE Puerto Rico, although different, is most similar to Point Judith in 1977, both scoring highest on all dimensions except Basic Needs where Point Judith 1977 is highest and SE Puerto Rico about average. Point Judith in 1977 differs from the contemporary NE Region US by having higher scores on all three job satisfaction components. Jamaica's scores, quite low on all components, contrasts with Belize, Nicaragua and the Dominican Republic (Figure 1). Total job satisfaction scores (sum of the three components) are plotted in Figure 2, indicating that SE Puerto Rico and Point Judith in 1977 manifest the overall highest scores while the Jamaican sample has the lowest.

\section{Table 3}

Mean values for job satisfaction variables on all three components across all locations $(\mathrm{N}=817)$.

\begin{tabular}{llll}
\hline \multirow{2}{*}{ Region } & \multicolumn{3}{c}{ Job Satisfaction Components } \\
\cline { 2 - 4 } & Basic Needs & Social \& Psychological & Self-Actualization \\
\hline Belize & 10.3 & 10.4 & 11.9 \\
Jamaica & 9.7 & 8.44 & 11.1 \\
Nicaragua & 10.5 & 11.3 & 11.6 \\
Dominican Republic & 10.6 & 11.1 & 11.4 \\
S. New England & 9.5 & 10.1 & 12.6 \\
N. New England & 10.4 & 11.1 & 12.7 \\
Mid-Atlantic & 9.8 & 11.1 & 13.1 \\
SE Puerto Rico & 10.2 & 12.0 & 14.5 \\
Point Judith 77 & 11.6 & 11.3 & 12.8 \\
\hline Kruskal-Wallis H & 54.388 & 64.434 & 161.839 \\
p-value & $<0.001$ & $<0.001$ & $<0.001$ \\
\hline
\end{tabular}




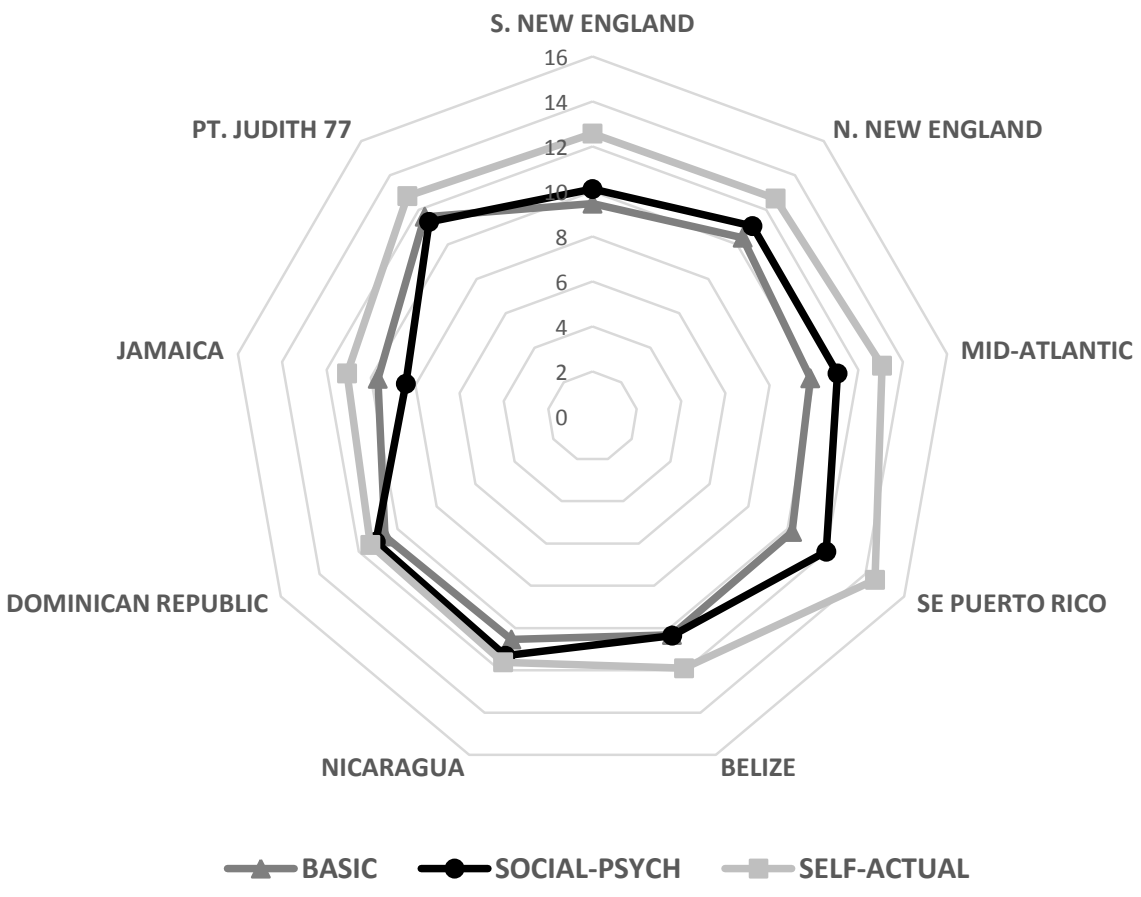

Figure 1.

- Title: Job Satisfaction among fishers for all regions.

- Subtitle: Scores on the three components of job satisfaction for all regions analyzed. 


\section{Least Squares Means}

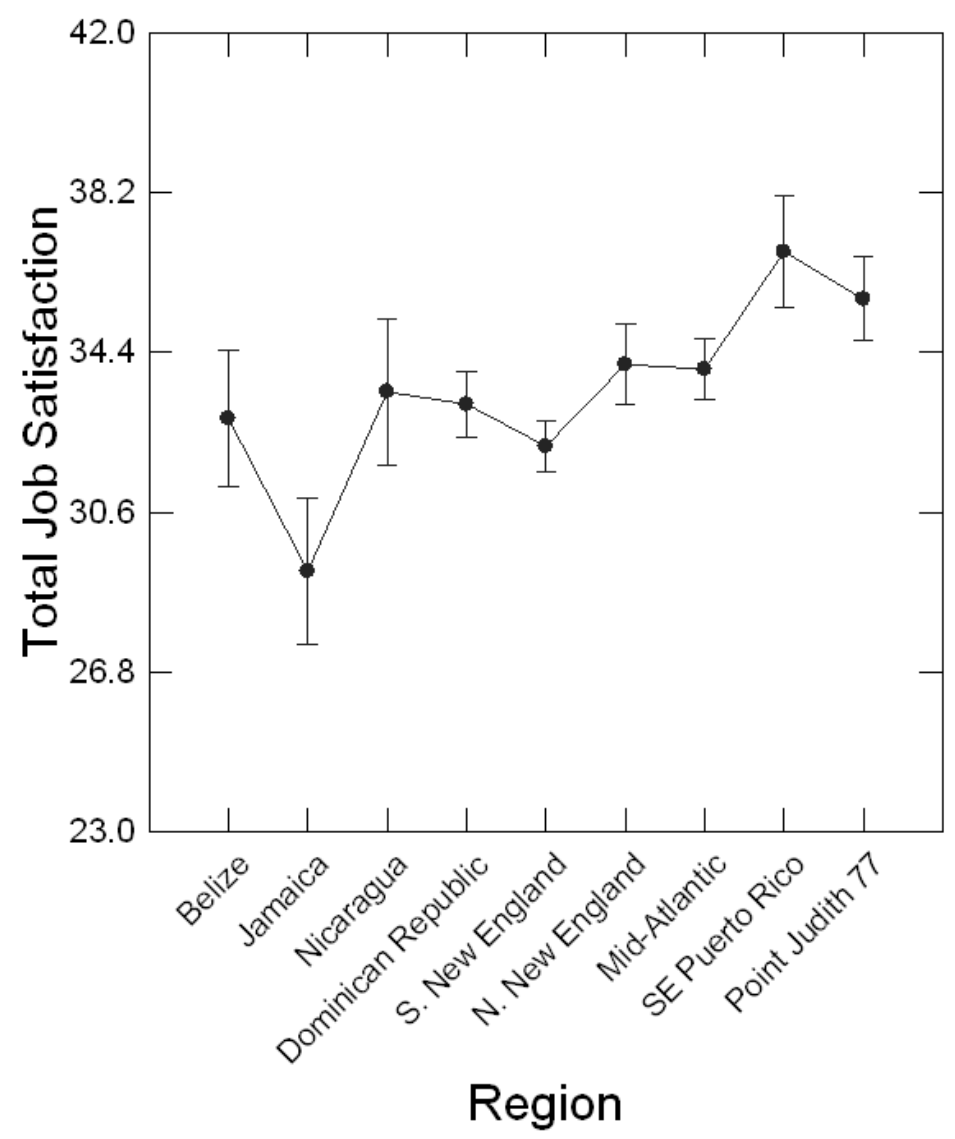

Figure 2.

- Title: Total job satisfaction scores by region.

- Subtitle: Sum of the scores on the three job satisfaction components (total job satisfaction) across all regions.

Table 4 displays percent distribution of responses to the two additional job satisfaction questions for all locations studied except for the second question which was not included in the wider Caribbean survey. Differences between samples are statistically significant (Chi square, $\mathrm{p}<0.001$ ), and the effect sizes are strong (Cramér's V $=0.41$ and 0.23 respectively). When these results are plotted (Figure 3), once again, similarities between Point Judith 1977 and the SE Puerto Rican sample can be observed. Turning to the influence of job satisfaction on these two variables, Table 5 indicates that those who report higher levels of satisfaction on the three job satisfaction components tend to respond "yes" to both questions (all $\mathrm{p}<0.01$ or better). 
Table 4

Percent distribution of fishers who would advise a young person to fish and who would still become a fisher if they had they life to live over.

\begin{tabular}{lllllll}
\hline \multirow{2}{*}{ Region } & \multicolumn{3}{c}{ Advise Young to Fish } & \multicolumn{3}{c}{ Still Become Fisher } \\
\cline { 2 - 7 } & No (\%) & Yes (\%) & N & No (\%) & Yes (\%) & N \\
\hline Belize & 71.0 & 29.0 & 31 & - & - & - \\
Jamaica & 15.4 & 84.6 & 26 & - & - & - \\
Nicaragua & 30.8 & 69.2 & 26 & - & - & - \\
Dominican Republic & 48.5 & 51.5 & 130 & - & - & - \\
S. New England & 66.1 & 33.9 & 236 & 29.2 & 70.8 & 236 \\
N. New England & 54.7 & 45.3 & 86 & 12.8 & 87.2 & 86 \\
Mid-Atlantic & 64.1 & 35.9 & 156 & 17.3 & 82.7 & 15 \\
SE Puerto Rico & 19.1 & 80.9 & 47 & 4.3 & 95.7 & 47 \\
Point Judith 77 & 7.6 & 92.4 & 79 & 7.6 & 92.4 & 79 \\
Total & 50.8 & 49.2 & - & 19.0 & 81.0 & - \\
N & 415 & 402 & 817 & 115 & 489 & 604 \\
\hline Chi Square & $\chi^{2}=134.1, \mathrm{df}=8, \mathrm{p}<0.001$ & $\chi^{2}=31.8, \mathrm{df}=4, \mathrm{p}<0.001$ \\
Cramér's V & 0.41 & \multicolumn{7}{c}{0.23} \\
\hline
\end{tabular}

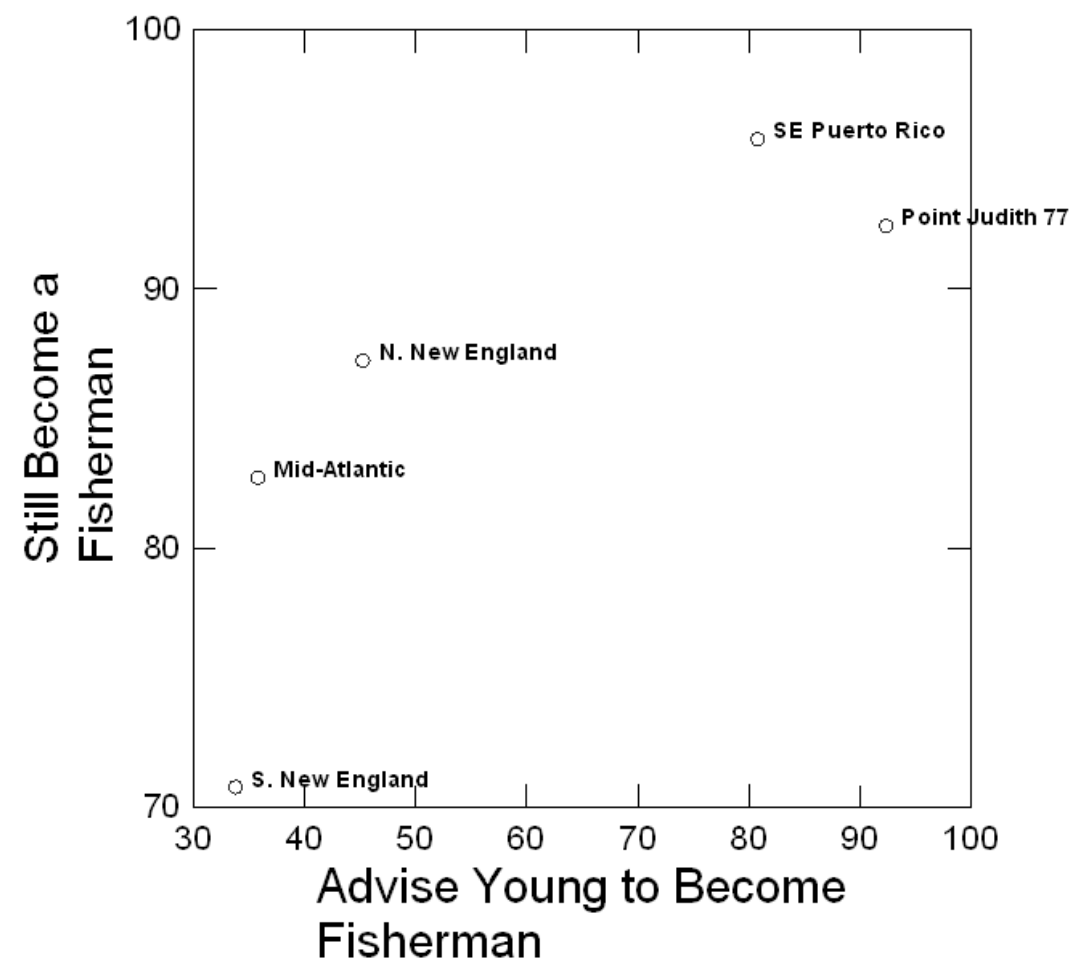

Figure 3.

- Title: Willingness to still become a fisher and to advise a young person to enter fishing across NE Region US and SE Puerto Rico

- Subtitle: Plots of percent of fishers in each region and sub-region who said that they would still become a fisher if they had their life to live over and percent who would advise a young person to go into fishing. 
Table 5

Difference in mean values for all three job satisfaction components as related to responses to the two job satisfaction questions on advising young to fish and still become a fisher.

\begin{tabular}{lcccccccc}
\hline Job Satisfaction Variables & Response & N & Mean & SD & t-value & DF & $\begin{array}{c}\text { Cohen's } \\
\text { D }\end{array}$ & r \\
\hline Advise Young to Fish & & & & & & & & \\
\hline Basic Needs & No & 410 & 9.451 & 2.519 & $8.637^{* *}$ & 790.2 & 0.614 & 0.294 \\
& Yes & 397 & 10.866 & 2.125 & & & & \\
Social \& Psychological Needs & No & 410 & 10.507 & 2.387 & $3.416^{*}$ & 806 & 0.241 & 0.119 \\
& Yes & 398 & 11.058 & 2.185 & & & & \\
Self-Actualization & No & 408 & 12.245 & 2.209 & $3.901^{* *}$ & 770.2 & 0.281 & 0.139 \\
& Yes & 400 & 12.790 & 1.739 & & & & \\
\hline Still Become Fisher & & & & & & & & \\
\hline Basic Needs & No & 113 & 8.982 & 2.912 & $4.386^{* *}$ & 150.8 & 0.714 & 0.336 \\
Social \& Psychological Needs & Yes & 481 & 10.279 & 2.432 & & & & \\
& No & 112 & 9.777 & 2.560 & $5.203 * *$ & 593 & 0.427 & 0.209 \\
Self-Actualization & Yes & 483 & 11.043 & 2.263 & & & & \\
& No & 113 & 11.858 & 2.546 & $6.152^{* *}$ & 594 & 0.5048 & 0.245
\end{tabular}

${ }_{\mathrm{A}} \mathrm{t}$-values in shaded boxes calculated on basis of separate variance.

$* * \mathrm{p}<0.001 ; * \mathrm{p}<0.01$

Tables 6 and 7 present the results of a Logistic regression analysis used to determine the combined effects of the three job satisfaction components on responses to these two questions for the entire sample. Since previous research has indicated that age and education might have impacts on these two variables (Crosson 2014; Pollnac and Poggie 1988, 2006; Pollnac et al. 2012, 2015), they were included in the analyses. Table 6 indicates that, with regard to advising a young person to fish, all the independent variables except Social \& Psychological Needs contribute statistically significantly to the dependent variable's variance (Naglekerke's $\mathrm{R}^{2}=$ $0.202, \mathrm{p}<0.001)$. As the job satisfaction components increase, so does willingness to advise a young person to go into fishing. The opposite relationship holds with age and education: as these two variables increase, there is reluctance to advise a young person to fish as an occupation. Naglekerke's $\mathrm{R}^{2}$ is similar to $\mathrm{R}^{2}$ in regression analysis, indicating the amount of variance explained in the dependent variable by the independent variables in the model. Numbers in the "estimate" column are analogous to beta weights in regression analysis, indicating that Basic Needs and Self-Actualization contribute to most of the variance in the dependent variable $(0.193$ and 0.146 , respectively). With regard to still becoming a fisher, Naglekerke's $\mathrm{R}^{2}=0.144$ $(\mathrm{p}<0.001)$ and all independent variables seen in Table 7 except age and education are statistically significant in the model $(\mathrm{p}<0.05)$. 
Table 6

Logistic regression analysis of variables predicted to influence advising a young person to get into fishing

\begin{tabular}{lllll}
\hline Parameter & Estimate & $\begin{array}{l}\text { Standard } \\
\text { Error }\end{array}$ & $\mathbf{Z}$ & p-value \\
\hline CONSTANT & 1.679 & 0.690 & 2.434 & 0.015 \\
Age & -0.040 & 0.006 & 6.595 & 0.000 \\
Education & -0.075 & 0.019 & 3.988 & 0.000 \\
Basic Needs & 0.193 & 0.036 & -5.415 & 0.000 \\
Social \& Psychological Needs & 0.033 & 0.036 & -0.932 & 0.352 \\
Self-Actualization & 0.146 & 0.043 & -3.407 & 0.001 \\
\hline
\end{tabular}

Naglekerke's $R^{2}=0.202, \chi^{2}=130.213, \mathrm{df}=5, \mathrm{p}<0.001, \mathrm{~N}=794^{*}$

"Total sample is different due to missing data.

Table 7

Logistic regression analysis of variables predicted to influence whether fishers would still become a fisher if they had their life to live over

\begin{tabular}{lcccc}
\hline Parameter & Estimate & $\begin{array}{c}\text { Standard } \\
\text { Error }\end{array}$ & $\mathbf{Z}$ & p-value \\
\hline CONSTANT & 3.406 & 1.040 & 3.275 & 0.001 \\
Age & -0.007 & 0.009 & 0.737 & 0.461 \\
Education & -0.014 & 0.037 & 0.366 & 0.714 \\
Basic Needs & 0.116 & 0.047 & -2.498 & 0.012 \\
Social \& Psychological Needs & 0.133 & 0.048 & -2.768 & 0.006 \\
Self-Actualization & 0.221 & 0.053 & -4.141 & 0.000 \\
\hline
\end{tabular}

Naglekerke's $\mathrm{R}^{2}=0.144, \chi^{2}=54.676, \mathrm{df}=5, \mathrm{p}<0.001, \mathrm{~N}=582^{*}$

*Total sample is different due to missing data.

Turning to the measure of individual well-being there is a statistically significant difference between the four regions (Figure 4) for which this data is available (the overall well-being question was not posed in the wider Caribbean sample) (Kruskal-Wallis analysis of variance, $\mathrm{H}$ $=54.602, \mathrm{p}<0.001)$. Similar to the job satisfaction variables, contemporary Southern New England presents the lowest and SE Puerto Rico the highest levels of well-being. Correlations between well-being and age, education and the job satisfaction variables are in Table 8 . All are statistically significant (all p<0.01 or better) except for education. Ordinal regression (Mcullagh 1980) using the logit function is employed to determine the combined effects of the independent variables on well-being (Table 9). Interpretation of the table is similar to Tables 6 and 7. Naglekerke's $\mathrm{R}^{2}$ indicates that about one-fourth of the variance in self-reported well-being is accounted for by the independent variables. All estimates are statistically significant (all $\mathrm{p}<0.05$ or better). Social \& Psychological Needs and Self-Actualization contribute to most of the variance in the dependent variable ( 0.181 and 0.251 , respectively). 
Least Squares Means

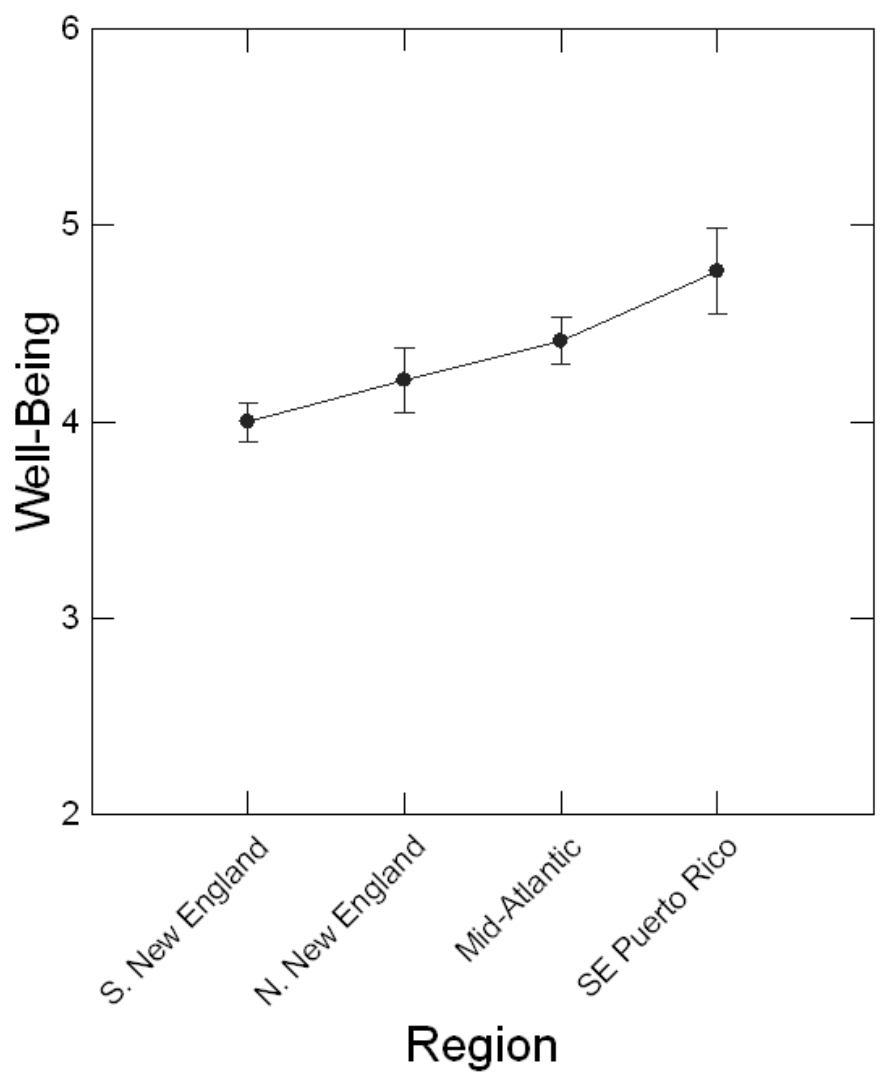

Figure 4.

- Title: Inter-regional differences in reported well-being.

- Subtitle: Plot of the scores on the well-being question comparing NE Region US sub-regions and SE Puerto Rico.

Table 8

Correlations (rho) between independent variables and well-being.

\begin{tabular}{lcc}
\hline Independent Variables & Well-Being & $\mathbf{N}^{\mathbf{A}}$ \\
\hline Age & $0.112^{*}$ & 521 \\
Education & -0.072 & 517 \\
Basic Needs & $0.239^{* *}$ & 514 \\
Social \& Psychological Needs & $0.305^{* *}$ & 515 \\
Self-Actualization & $0.390^{* *}$ & 515
\end{tabular}

${ }^{\mathrm{A}} \mathrm{N}$ varies due to missing data

$* \mathrm{p}<0.01, * * \mathrm{p}<0.001$ (one-tail probabilities) 
Table 9

Ordinal regression between independent variables and well-being.

\begin{tabular}{lccc}
\hline Parameter & Estimate & $\begin{array}{c}\text { Standard } \\
\text { Error }\end{array}$ & p-value \\
\hline Age & 0.020 & 0.007 & 0.005 \\
Education & -0.063 & 0.027 & 0.019 \\
Basic Needs & 0.129 & 0.038 & 0.001 \\
Social \& Psychological Needs & 0.181 & 0.041 & $<0.001$ \\
Self-Actualization & 0.251 & 0.047 & $<0.001$ \\
\hline
\end{tabular}

Naglekerke's $R^{2}=0.234, \chi^{2}=116.20, \mathrm{df}=5, \mathrm{p}<0.001$ (Link function: logit)

\section{Discussion and Conclusions}

This paper focused on comparing contemporary SE Puerto Rican and NE Region US survey data to further investigate aspects of fishers' relationships with the occupation and factors affecting job satisfaction and well-being among fishers. Other regions in the non-US Caribbean as well as data from Point Judith, RI from 1977 were also used to provide context and enrich the analyses by using geographic and temporal comparisons. The core of this paper is based on fishers' scores on nine job satisfaction variables grouped into three components: Basic Needs, Social \& Psychological Needs, and Self-Actualization. Use of the truncated job satisfaction indicators is supported by the principal component analysis presented in Table 2 which resulted in components analogous to those in earlier analyses (see methods section for more detail). When available, two additional job satisfaction questions on willingness to advise a young person to fish and to still become a fisher if one could live their life over, as well as data on subjective levels of well-being based on fishers' perception of their satisfaction with their lives in general were also analyzed to further support the main arguments of this study.

Although previous research (Griffith and Valdes-Pizzini 2002; Pollnac et al. 2011) suggested that SE Puerto Rican fishers would score higher than US fishers on the Social \& Psychological Needs component of job satisfaction, their much higher score on that as well as on the SelfActualization component was surprising (Table 3), leading to the highest overall job satisfaction score of all the regions analyzed (Figure 2). Comparisons using contemporary data from the wider Caribbean sample and archive data from 1977 Point Judith fishers help explain these results.

Comparisons of SE Puerto Rican fishers with other Caribbean small-scale fishers (Table 3 and Figure 1) also reflect higher scores on both the Self-Actualization and Social \& Psychological Needs components. Jamaica's quite low score on the Social \& Psychological Needs component is likely due to a longer fishing trip length, which distinguishes it from the other Caribbean 
locations. This relationship between trip length and job satisfaction was also reported for the New England fishery (Pollnac and Poggie 1988). SE Puerto Rico's relatively high and Jamaica's very low scores on Self-Actualization cannot be easily explained.

The only component where other Caribbean fishers scored slightly higher than SE Puerto Rico was Basic Needs, but the difference is not statistically significant (Mann-Whitney $U=5,293.5, p$ $>0.05$ ). The relatively high levels on the Basic Needs component, despite disparities in income between the countries, suggests that incomes, their predictability, and job safety levels are considered satisfactory to most fishers in the sample.

Interestingly, the aggregated data shows that the contemporary SE Puerto Rican and 1977 Point Judith samples reflect the highest overall job satisfaction of the populations compared in this analysis (Figure 2). Point Judith in 1977 had a relatively high score in the Basic Needs component-higher than SE Puerto Rico today - but Self-Actualization in SE Puerto Rico is higher than Point Judith's, although in 1977 Point Judith scored relatively high on that component as well. SE Puerto Rico is also the sample with the highest score on Social \& Psychological Needs, as expected, supporting the hypothesis that activities performed are "therapeutic" as reported by Griffith and Valdes-Pizzini (2002). Percent positive responses to the two questions concerning advising a young person to enter the occupation of fishing and the respondents' willingness to still become fishers if they had their lives to live over further support the observations concerning the closeness of contemporary SE Puerto Rican and Point Judith in 1977 with regard to job satisfaction (Figure 3).

What is it about SE Puerto Rico and 1977 Point Judith that results in this similarly high evaluation of job satisfaction among fishers? The social-ecological environment of both the contemporary SE Puerto Rican and 1977 Point Judith fishers was one of considerable freedom to pursue their own inclinations in fishing, other livelihood activities, and spend time with friends and family, coupled with a sufficient material well-being to not be motivated by needs influenced by the lower standard of living that characterizes the other Caribbean samples (Pollnac et al. 2012). Additionally, the 1977 Point Judith data was collected the year after the Fishery Conservation and Management Act (FCMA) was passed and thus well before the full effects of the Act had taken hold and before the tightening of fisheries regulations that occurred in the 1990s and 2000s. The year 1977 was also a time of extreme optimism in US fisheries. The federal government was providing subsidies to boost the national fisheries after excluding foreign vessels from the US Exclusive Economic Zone. This optimism is most likely reflected in fishers' overall satisfaction with their occupation in 1977. By 2011, NE Region US fishers' perceptions of the unpredictability, complexity and unfairness of the changing regulations had a negative impact on overall job satisfaction (Pollnac et al. 2015). 
In brief, fishers in Point Judith in the late 1970's had flexibility-the ability to more easily switch between species and gear and other adaptive mechanisms that buffer them from the vicissitudes of the environment and economy. Point Judith in 1977 had an extremely successful fishers' cooperative and SE Puerto Rican fishers have strategic occupational multiplicity. Both areas were characterized by a close-knit fishing community with strong kinship relationships between fishers. The social relationships in both were facilitated by relatively short fishing trips (one to two days) in comparison to the longer trips found among most NE Region US and Jamaican fishers today. Trip length is the factor that most likely influences scores on the Social \& Psychological Needs component (Pollnac and Poggie 1988), which includes levels of satisfaction with "time spent away from home." Fishers who are not removed from their social circles, including family and other community members for an extended period of time are more likely to manifest higher scores on this component. The time out at sea also influences aspects of healthfulness and fatigue also included in this component-fishers are often sleep deprived during long trips, working overnight or for extended periods of time during the day and evening. Day fishers in SE Puerto Rico and primarily one to two day fishers in 1977 Point Judith (85\%, $15 \%$ fished for 3 days) most likely did not experience this type of stress; hence, fishing for these fishers is more likely considered as "therapy." We would also like to suggest that the occupation of fishing can also be considered as "therapy" in that it provides satisfactions for the personality type associated with fishing - a personality type that enjoys the adventures of fishing (Glazier 2007; Pollnac and Poggie 2006) the thrill of the chase, being out on the ocean, striving to recapture what Glazier (2007) refers to as the "peak experience."

Regarding analyses involving the question on advising young to fish, fishers in the NE Region US today often say that they do not advise people to get into fishing because of the impacts of regulations on the activity. Not only because it is more difficult to get into the fishery and make money now, but also because of the "hassle" associated with complying with all the regulations. This, most likely, partially explains the relatively low willingness to advise young people to fish in the NE Region US nowadays in comparison to the Caribbean and 1977 Point Judith. Higher levels of job satisfaction on all three components (Table 5) also explains part of this variance: the more satisfied fishers are with their occupation, the more willing they are to advise young people to fish for a living. Job satisfaction also clearly influences whether or not fishers would enter the occupation again if they had the opportunity to live their lives over.

The analyses concerning how the impact of job satisfaction components compare to other important variables such as age and education indicate that while the job satisfaction components, except for Basic Needs, manifest relatively high statistically significant positive weights, age and education manifest weak negative weights concerning willingness to advise a young person to enter the occupation of fishing (Table 6). Turning to desire to become a fisher again, age and education are not related while the job satisfaction components account for the most variance in the data set (Table 7). 
With regard to the important variable of well-being (in the Caribbean it was only evaluated in SE Puerto Rico), we find, as expected, that higher levels of job satisfaction components account for the most variance, older age accounts for a little more, and education level has a relatively weak negative influence. This clearly suggests that the therapeutic value of fishing, reflected in the job satisfaction scores, positively influences the lives of its participants.

Finally, the earlier job satisfaction papers interpreting fishing as therapy (Griffith and ValdesPizzini 2002; Pollnac et al. 2011) were focused on one aspect of job satisfaction-social and psychological needs. Here we would like to argue that therapy encompasses more - that it should include the relatively ubiquitous satisfaction of needs for adventure, risk and the thrill of the chase (Beauchaine and Gatzke-Kopp 2012; Pollnac and Poggie 2006, 2008; Pollnac et al. 2012) (Self Actualization needs). We have argued in a previous study that the occupation of fishing selects for individuals manifesting a personality complex referred to as an externalizing disposition (Pollnac and Poggie 2006). This personality complex has been found to have a relatively large genetic component (Hicks et al. 2004; LeGrand et al. 2005). The genetic component of human behavior is supported by a growing body of research and is increasingly accepted among behavioral scientists (Baker 2004; Derringer et al. 2010). Therapy for this type of personality would consist of satisfying the needs for adventure, risk and the other attributes included in the self-actualization aspect of job satisfaction among fishers. We find it interesting that Griffith and Pizzini (2002) note that fishers stated that the therapy of fishing keeps them away from drugs and other vices, as well as keeping young people away from delinquencyother behavioral consequences of this personality type mentioned in Hicks et al. 2004 and LeGrand et al. 2005. Without this therapy provided by fishing the individual will suffer from the consequences of job dissatisfaction ranging from psychosomatic illness to less longevity and family violence — all related to individual well-being (Pollnac et al. 2008).

For example, while performing a face-to-face interview with a fisher that had nothing to do with job satisfaction, the fisher said he had left fishing after pressure from his family and that he came back because he could not endure his new job which was related to some of the skills he learned while fishing (refrigeration). He also noted that the situation became so intolerable he began to drink more and ended up in jail for domestic abuse (he beat his wife). He reported that his subsequent return to fishing solved his marital and other problems - he returned to the "therapy" of a fisher's life.

Hence, we argue that situations that force a fisher to leave the fishery, to abandon the therapeutic benefits it may provide, can result in the above mentioned negative consequences. There are, of course, extreme sports and other occupations (e.g., soldier, policeman, venture capitalist, test pilots, fire fighters, etc.), which can satisfy some of the needs of self-actualization. For example, in a discussion with a firefighter who had left the fishery, he likened the ringing of the alarm and 
the subsequent leaving the firehouse in the fire truck as being very similar to leaving the dock to go fishing - a feeling of an adventure about to occur, anticipation of the unknown possibilities of the activity. But we must ask, how many of these alternate activities are available or even appropriate for the displaced fisher?

These examples are not isolated incidents. In the process of the hundreds of interviews with fishers all the authors have heard many fishers, in the US and elsewhere, wax poetic concerning experiences they have had while fishing - examples of the "peak experience" as described by Glazier (2007: 122-123) for the Hawaiian fishery where "unforgettably positive experiences" achieved while fishing contribute to continuing participation in the occupation.

Overall the high levels (average scores are over the midpoint for all samples) of job satisfaction found among Caribbean and the NE Region US fishers sampled in this study support previous literature evidencing fishers' special attachment to their occupation. Certain aspects of fishing that can be described as "therapeutic," not often found in other jobs, can help explain this important attachment. Comparisons of the highly restrictive management environment of the NE Region US to the less restrictive SE Puerto Rico and 1977 Point Judith provide clear evidence that changes in the regulatory environment can have significant impacts on levels of job satisfaction among fishers.

Unsurprisingly, levels of job satisfaction and overall well-being were found to be correlated with each other. Often, regulations aim at controlling effort by reducing the number of boats and consequently forcing fishers out of the fishery. These management decisions can have serious implications for fishers and their family's well-being even if alternative income is available (Sievanen et al. 2005). Negative impacts to overall aspects of well-being such as happiness and peacefulness can result in damaging social impacts to individuals and their communities (see Pollnac et al. 2008). Taking into account aspects of fishers' job satisfaction can help shape future fisheries conservation and management strategies that maintain and promote well-being in fishing communities while helping preserve the fish resources upon which they depend.

\section{Acknowledgments}

Funding for the research upon which this article was based was provided by several different sources. The Puerto Rico data was collected under a research grant from the NOAA - University of Puerto Rico Sea Grant College Program. The non-US Caribbean data was collected as part of an interdisciplinary research project ( $\mathrm{nr}$ 003711) with the acronym ECOST coordinated by the University of Portsmouth (UK) and funded by the European Commission FP6 program. The recent Northeast Region US data was collected under a National Marine Fisheries Service, NOAA contract, number EA133F10SE2694. The 1977 data collection was funded by a National Science Foundation Grant No AER 77-06018. Opinions and conclusions expressed or implied 
are those of the authors and do not necessarily reflect the views of any of the above mentioned funding organizations.

\section{References}

Abunge, C., S. Coulthard, and T. M. Daw. 2013. Connecting Marine Ecosystem Services to Human Well-being: Insights from Participatory Well-being Assessment in Kenya. AMBIO 42:1010-1021.

Acheson, J. M., R. B. Pollnac, J. J. Poggie, and J. A. Wilson. 1980. Study of social and cultural aspects of fisheries management in New England under extended jurisdiction (3 vol., 271, 111, 389 p.). Washington, D.C., Kingston, Rhode Island, and Orono, Maine: National Science Foundation, University of Rhode Island, and University of Maine, NSF grant AER77-06018.

Anderson, L. G. 1980. Necessary components of economic surplus in fisheries economics. Canadian Journal of Fisheries and Aquatic Science 37(5):858-870.

Apostle, R. L., L. Kasdan, and A. Hanson. 1985. Work satisfaction and community attachment among fishermen in Southwest Nova Scotia. Canadian Journal of Fisheries and Aquatic Science 42(2):256-267.

Baker, C. 2004. Behavioral Genetics. Washington, DC: American Association for the Advancement of Science.

Beauchaine, T. P. and L. M. Gatzke-Kopp. 2012. Instantiating the multiple levels of analysis perspective in a program of study on externalizing behavior. Development and Psychopathology 24:1003-1018.

Binkley, M. 1995. Risks, dangers and rewards in the Nova Scotia offshore fishery. Montreal: McGill-Queen's University Press. 192 p.

Bowen, R. E., and C. Riley. 2003. Socio-economic indicators and integrated coastal management. Ocean and Coastal Management 46:299-312.

Bunce, L., P. Townsley, R. Pomeroy, and R. B. Pollnac. 2000. Socioeconomic manual for coral reef management. Townsville, Queensland : Australian Institute of Marine Science.

Clay, P. M., A. Kitts, and P. P. Da Silva. 2014. Measuring the social and economic performance of catch share programs: Definition of metrics and application to the U.S. Northeast Region groundfish fishery. Marine Policy 44: 27-36.

Crosson, S. 2014. Anticipating Exit from North Carolina's Commercial Fisheries. Society and Natural Resources 28:797-806. 
Daw, T. M., C. Hicks, K. Brown, T. Chaigneau, F. Januchowski-Hartley, W. Cheung, S. Rosendo, B. Crona, S. Coulthard, C. Sandbrook, C. Perry, S. Bandeira, N. A. Muthiga, B. Schulte-Herbrüggen, J. Bosire, and T. R. McClanahan. 2016. Elasticity in ecosystem services: exploring the variable relationship between ecosystems and human well-being. Ecology and Society 21(2):11. http://dx.doi.org/10.5751/ES-08173-210211

Derringer, J., R. F. Krueger, D. M. Dick, S. Saccone, R. A. Grucza, A. Agrawal, P. Lin, L. Almasy, H. J. Edenberg, T. Foroud, J. I. Nurnberger, Jr., V. M. Hesselbrock, J. R. Kramer, S. Kuperman, B. Porjesz, M. A. Schuckit, and L. J. Bierut. 2010. Predicting Sensation Seeking From Dopamine Genes: A Candidate-System Approach. Psychological Science 21(9):12821290.

Garcia-Quijano, C., J. J. Poggie, and M. Del Pozo (2016). "En el Monte También Se Pesca: 'Pesca de Monte', ambiente, subsistencia y comunidad en los bosques costeros del sureste de Puerto Rico" ("Pesca de Monte:" Environment, subsistence, and community in the Coastal Forests of Southeastern Puerto Rico). Caribbean Studies 43 (2): 115-144..

Garcia-Quijano, C., J. J. Poggie, A. Pitchon, and M. Del Pozo. 2015. Coastal resource foraging, life satisfaction, and well-being in Southeastern Puerto Rico. Journal of Anthropological Research 71(2): 145-167.

Garcia-Quijano, C., J. Poggie, A. Pitchon, M. Del Pozo, and J. Alvarado. 2013. The coast's bailout: Coastal resource use, quality of life, and well-being in Southeastern Puerto Rico. Technical report NOAA - University of Puerto Rico Sea Grant.

Gatewood, J. B., and B. J. Mccay. 1990. Comparison of job satisfaction in six New Jersey fisheries. Human Organization 49(1):14-25.

Glazier, E. W. 2007. Hawaiian Fishermen. Belmont, CA: Thompson Wadsworth Corp. Griffith D., M. Valdes-Pizzini, and C. Garcia-Quijano. 2007. Entangled communities: Socioeconomic profiles of fishers, their communities, and their responses to marine protective measures in Puerto Rico. NOAA Series on U.S. Caribbean Fishing Communities. NOAA Technical Memorandum NMFS-SEFSC-556, 524 p. Agar, J. J. And B. Stoffle (Eds.).

Griffith, D., and M. Valdes-Pizzini. 2002. Fishers at work, workers at sea - A Puerto Rican journey through labor and refuge. Philadelphia, PA: Temple University Press. 265 p.

Hicks, B.M., R.F. Krueger, W.G. Iacono, M. McGue and C.J. Patrick. 2004. Family Transmission and Heritability of Externalizing Disorders: A Twin-family Study. Archives of General Psychiatry 61:922-928. 
Kildow, J. T., C. S. Colgan, J. D. Scorse, P. Johnston, and M. Nichols. 2014. State of the U.S. Ocean and Coastal Economies 2014. Publications. Paper 1. http://cbe.miis.edu/noep_publications/1

Legrand, L., W. G. Iacono, and M. McGue. 2005. Predicting addiction. American Scientist 93:140-147.

McCay, B. J., J. B. Blinkoff, R. Blinkoff, and D. Bart. 1993. Fishery impact management project: Report, part. 2, phase 1, to the Mid-Atlantic Fishery Management Council. Dover, DE: Mid-Atlantic Fishery Management Council.

Mcullagh, P. 1980. Regression models for ordinal data. Journal of the Royal Statistical Society, Series B (Methodological), Vol. 42, No. 2(1980), pp. 109-142

Monnereau, I., and R. B. Pollnac. 2012. Which fishers are satisfied in the Caribbean? A comparative analysis of job satisfaction among Caribbean lobster fishers. Social Indicators Research 109(1): 95-118.

MSFCMA (Magnuson-Stevens Fishery Conservation and Management Act) Reauthorization of 2007, 16 U.S. Code $\S 1851$ (a)(8). Online at:

http://www.nmfs.noaa.gov/sfa/magact/MSA_Amended_2007\%20.pdf

Olson, J. 2011. Understanding and contextualizing social impacts from the privatization of fisheries: An overview. Ocean \& Coastal Management 54(5): 353-363.

Oswald, A. J. and S. Wu. 2010. Objective confirmation of subjective measures of human wellbeing: Evidence from the USA. Science 327(5965):576-579.

Pascoe, S., T. Cannard, E. Jebreen, C. M. Dichmont, and J. Schirmer. 2015. Satisfaction with fishing and the desire to leave. Ambio 44:401-411.

Pérez, R. 2005. The state and small-scale fisheries in Puerto Rico. Gainesville, FL: University of Florida Press.

Poggie, J., and C. Gersuny. 1974. Fishermen of Galilee: The human ecology of a New England coastal community. University of Rhode Island Sea Grant Marine Bulletin Series No. 17. Narragansett, RI: University of Rhode Island Sea Grant.

Pollnac, R. B., and J. J. Poggie. 1980. Perceptions of the occupation of small-scale fishermen. In J. Sutinen and R. B. Pollnac (Eds.), Small-scale fisheries in Central America: Acquiring information for decision making (243-265). Kingston, RI: International Center for Marine Resource Development, University of Rhode Island. 
Pollnac, R. B., and J. J. Poggie. 2006. Job satisfaction in the fishery in two Southeast Alaskan towns. Human Organization 65(3):329-339.

Pollnac, R. B., and J. J. Poggie. 2008. Happiness, well-being and psychocultural adaptation to the stresses associated with marine fishing. Human Ecology Review 15(2):194-200.

Pollnac, R. B., and R. Ruiz-Stout. 1977. Artisanal fishermen's attitudes toward the occupation of fishing in the Republic of Panama. In R. B. Pollnac (Editor), Panamanian small-scale fishermen (16-21). Kingston, RI: International Center for Marine Resource Development, University of Rhode Island.

Pollnac, R. B., and J. J. Poggie. 1988. The structure of job satisfaction among New England fishermen and its application to fisheries management policy. American Anthropologist 90(4):888-901.

Pollnac, R. B., I. Monnereau, V. Ruiz, J. Poggie, and A. Westwood. 2011. Stress and the occupation of fishing. In Langan-Fox J. And Cooper C. L., (Eds.), Handbook of Stress in the Occupations (309-321). Chichester, UK: Edward Elgar Publishing.

Pollnac, R. B., M. Bavinck and I. Monnereau. 2012. Job satisfaction in fisheries compared. Social Indicators Research 109(1):119-133.

Pollnac, R. B., S. Abbott-Jamieson, C. Smith, M. L. Miller, P. M. Clay, and B. Oles. 2008. Toward a model for fisheries social impact assessment. Marine Fisheries Review 68(1-4):1-18.

Pollnac, R. B., T. Seara, and L. L. Colburn. 2015. Aspects of fishery management, job satisfaction, and well-being among commercial fishermen in the Northeast Region of the United States. Society \& Natural Resources 28(1):75-92.

Robinson, J., R. Athanisou, and K. Head. 1969. Measures of occupational attitudes and occupational characteristics. Ann Arbor, MI: Institute for Social Research, University of Michigan.

Sievanen L., B. Crawford, R. B. Pollnac, and C. Lowe. 2005. Weeding through assumptions of livelihood approaches in ICM: Seaweed farming in the Philippines and Indonesia. Ocean \& Coastal Management 48(3-6):297-313.

Smith, C. L. 1981. Satisfaction bonus from salmon fishing: Implications for economic evaluation. Land Economics 57(2):181-194.

Sweke. E. A., Y. Kobayashi, M. Makino, and Y. Sakurai. 2016. Comparative job satisfaction of fishers in northeast Hokkaido, Japan for coastal fisheries management and aquaculture development. Ocean \& Coastal Management 120:170-179. 
Trimble, M., and D. Johnson. 2013. Artisanal fishing as an undesirable way of life? The implications for governance of fishers' wellbeing aspirations in coastal Uruguay and southeastern Brazil. Marine Policy 37:37-44.

UNEP (United Nations Environment Programme). 2006. Marine and coastal ecosystems and human well-being: A synthesis report based on the findings of the Millennium Ecosystem Assessment. UNEP. 76pp. http://www.unep.org/pdf/Completev6_LR.pdf 